\title{
Distribution of nano-sized Cyanobacteria in the western and central Pacific Ocean
}

\author{
Mitsuhide Sato*, Fuminori Hashihama, Satoshi Kitajima, Shigenobu Takeda, \\ Ken Furuya
}

Department of Aquatic Biosciences, The University of Tokyo, Yayoi 1-1-1, Bunkyo-ku, Tokyo 1138657, Japan

\begin{abstract}
We investigated the distribution of nano-sized unicellular Cyanobacteria (nanocyanobacteria) in the Pacific Ocean. Nanocyanobacteria were distributed in the mixed layer throughout the western and central regions of the North and South Pacific subtropical gyres, where nitrate depletion and high irradiance are maintained throughout the year. Their maximum occurrence of $>5 \times 10^{9}$ cells m${ }^{-2}$ was found between 12 and $27^{\circ} \mathrm{N}$ and 10 and $21^{\circ} \mathrm{S}$. These areas with high nanocyanobacterial abundance largely correspond with those with high nitrogen fixation activity. In particular, the biomass of nanocyanobacteria was comparable with or larger than Synechococcus between 10 and $20^{\circ} \mathrm{N}$, while in the other regions, Synechococcus was overwhelmingly dominant. Where phosphorus was exhausted at the surface, they were comparatively sparse, even within the western subtropical gyres. In the subtropical and tropical provinces other than the western subtropical gyres, nanocyanobacteria were very sparse, even under similar nutrient conditions where nitrate was depleted and phosphorus was detectable. They may be competing with pico-sized Synechococcus and large filamentous diazotrophic Cyanobacteria Trichodesmium for various resources. Their patchy distribution suggests that the mechanism of nitrogen cycling also varies patchily in the oligotrophic region of the Pacific Ocean.
\end{abstract}

KEY WORDS: Picophytoplankton · Nanophytoplankton $\cdot$ Cyanobacteria $\cdot$ Synechococcus $\cdot$ Pacific subtropical gyres $\cdot$ Cross-basin distribution $\cdot$ Nitrogen fixation

\section{INTRODUCTION}

The North and South Pacific subtropical gyres are characterized by nanomolar surface nutrient concentrations throughout the year (Longhurst 2007). The surface chlorophyll a ( $\mathrm{chl}$ a) concentration is constantly $<0.1 \mu \mathrm{g} \mathrm{l}^{-1},>80 \%$ of which occurs in the $<3 \mu \mathrm{m}$ size fraction (Ishizaka et al. 1994). The phytoplankton community is numerically dominated by pico-sized (0.2 to $2 \mu \mathrm{m}$ ) unicellular Cyanobacteria, Prochlorococcus and Synechococcus (Campbell \& Vaulot 1993). They are probably able to incorporate nutrients at extremely low levels more efficiently than can larger nano- and microphytoplankton, owing to their relatively high surface:volume ratio.

Recently, the constant occurrence of nano-sized ( 2 to $20 \mu \mathrm{m})$, typically $>3 \mu \mathrm{m}$, unicellular, free-living Cyano- bacteria has been reported from the subtropical and tropical waters of the Pacific (Ishizaka et al. 1994, Neveux et al. 1999, Campbell et al. 2005) and Atlantic oceans (Li \& Wood 1988, Falcón et al. 2004b). Apparently they are expected to be more vulnerable to nutrient limitation than smaller picophytoplankton, owing to their low surface:volume ratio, when they compete for the same nutrient resources. Some researchers have succeeded in isolating them from natural waters, reporting that they include the diazotrophic Cyanobacteria genus Crocosphaera, which can grow in the absence of inorganic nitrogenous nutrients. Nitrogen fixation is one of the main processes that drive nitrogen cycling in the open oceans. Model calculations unequivocally demonstrate that nitrogen fixers contribute to a significant fraction of new production in the nitrate-depleted subtropical and tropical waters (Gru- 
ber \& Sarmiento 1997, Deutsch et al. 2001). Additionally, gaseous nitrogen fixation provides the nitrogenlimiting ocean surface with reduced nitrogen, which is available to nondiazotrophs after regeneration by zooplankton or released in the form of dissolved organic compounds (Capone et al. 1994). Traditionally, oceanic nitrogen fixation was considered to be carried out mainly by the filamentous Cyanobacteria of the genus Trichodesmium in the oligotrophic subtropical and tropical waters (Capone et al. 1997). However, after recent observations, nano-sized unicellular Cyanobacteria (nanocyanobacteria) are gaining increasing attention from biogeochemists as important marine nitrogen fixers (Montoya et al. 2004, Kitajima et al. 2009). Molecular biological techniques have revealed that the genes attributable to the nano-sized diazotrophic Cyanobacteria occur extensively in subtropical and tropical waters including the Pacific Ocean (Zehr et al. 2001, Falcón et al. 2004a, Church et al. 2005), Atlantic Ocean (Falcón et al. 2004a, Langlois et al. 2005), Arabian Sea (Mazard et al. 2004) and in Pacific temperate waters (Needoba et al. 2007).

While their potential significance in biogeochemical material cycling in the subtropical ocean is well recog- nized, global distribution of nano-sized Cyanobacteria and their environmental controlling factors are still unknown, since previous observations were performed at single sites or within small areas. Therefore, we conducted extensive surveys of the abundance of the nanocyanobacteria in the Pacific Ocean to reveal their cross-basin distribution. We also discuss what environmental factors determine their distribution, as the first step to elucidate their macroecological characteristics and role in the global biogeochemical flux of materials.

\section{MATERIALS AND METHODS}

Samples were collected during 8 cruises in the Pacific Ocean and the adjacent Coral and Tasman seas (Fig. 1). A total of 794 samples were analyzed, 347 of which were depth-profile samples obtained from 41 different stations during the KH-03-1, KH-03-2, KH05-2 and KH-08-2 cruises aboard the RV 'Hakuhomaru'. Depth-profile water was collected using Niskin$\mathrm{X}$ water samplers mounted on a carousel equipped with a CTD. During the KH-04-5, KH-05-2 and KH-082 cruises and the Umitaka-maru 0407 cruise on the

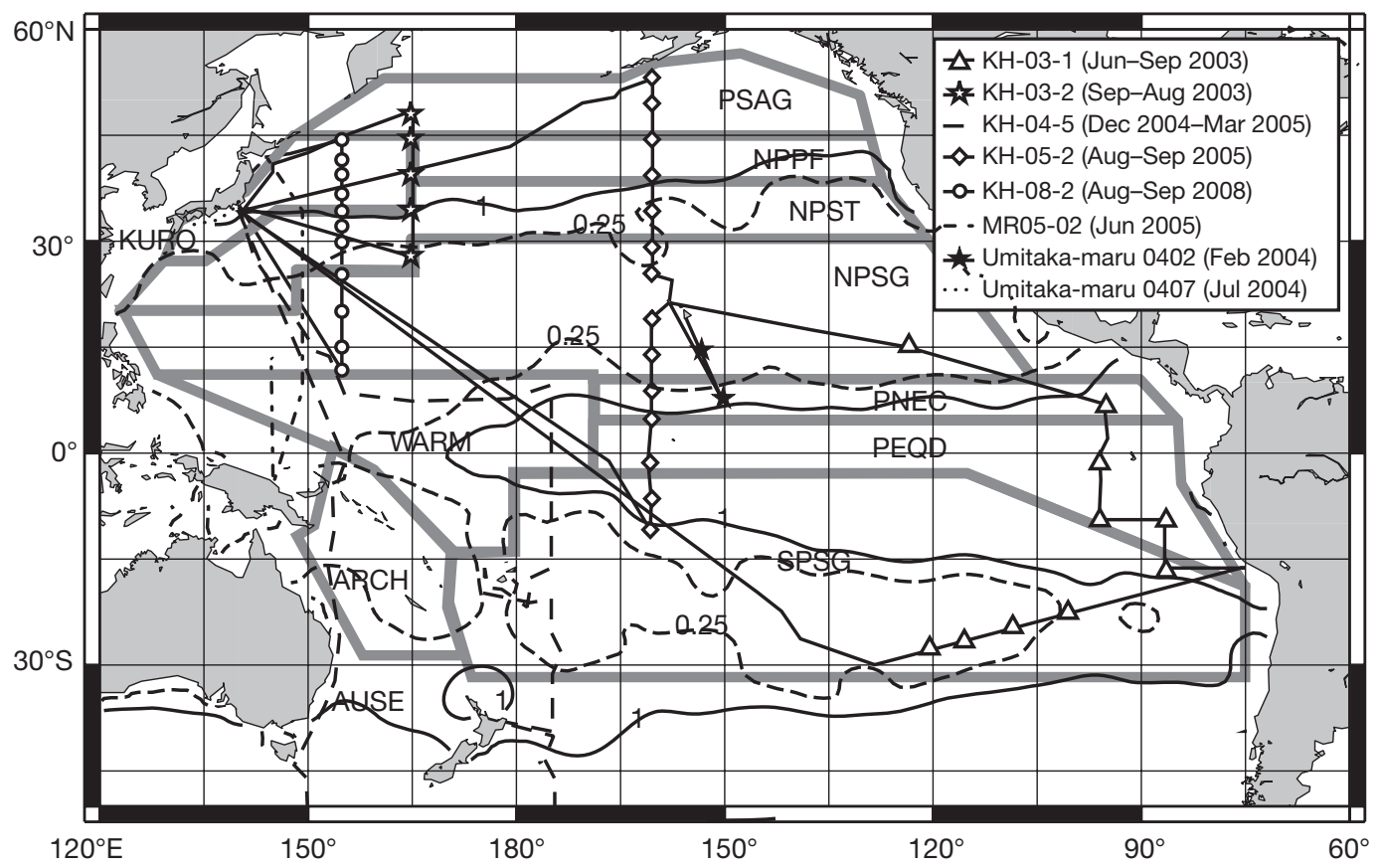

Fig. 1. Eight cruise tracks and sampling stations, superimposed on annual average nitrate concentration at the surface. Symbols on the cruise tracks indicate the sampling stations where vertical profiles were obtained. Contours of nitrate ( 0.25 and $1 \mu \mathrm{M}$ ) were derived from the World Ocean Atlas 2005. Gray lines correspond to boundaries of ecological provinces as defined by Longhurst (2007). PSAG: Pacific Subarctic Gyre Province; KURO: Kuroshio Current Province; NPPF: North Pacific Polar Front Province; NPST: North Pacific Subtropical Province; NPSG: North Pacific Subtropical Gyre Province; WARM: Western Pacific Warm Pool Province; PNEC: North Pacific Equatorial Countercurrent Province; PEQD: Pacific Equatorial Divergence Province; AUSE: East Australian Coastal Province; ARCH: Archipelago Deep Basins Province; SPSG: South Pacific Subtropical Gyre Province 
RTV 'Umitaka-maru', semi-continuous sampling of the surface ( $5 \mathrm{~m}$ depth) water was obtained from a pump located underneath the ship. Simultaneously, temperature and salinity of the pumped water were recorded by a sensor. During the Umitaka-maru 0402 cruise and the MR05-02 cruise on board the RV 'Mirai', surface waters were discretely sampled by using an acidwashed plastic bucket. The KH-04-5 cruise and the Umitaka-maru 0402 cruise were conducted in boreal winter, while the other 6 cruises were conducted in summer or early fall.

During the KH-03-2, KH-05-2 and KH-08-2 cruises, the samples were subjected to flow cytometry without fixation within $2 \mathrm{~h}$ after collection. The samples collected during the other cruises were fixed with glutaraldehyde at a final concentration of $1 \%$, frozen in liquid nitrogen and stored at $-80^{\circ} \mathrm{C}$ until analysis on shore.

Flow cytometric analysis was performed using a PAS-III flow cytometer (Partec) equipped with a $488 \mathrm{~nm}$ argon laser. The laser power was adjusted to 10 to $100 \mathrm{~mW}$, according to the autofluorescence intensities of the phytoplankton cells within the samples. The sample flow rate was set to approximately $10 \mu \mathrm{s}^{-1}$ and at least $250 \mu \mathrm{l}$ aliquots from each sample were subjected to analysis, indicating that the detection limit in the present study was $<4$ cells $\mathrm{ml}^{-1}$. The sample flow rate was calibrated by analyzing the suspension of a known concentration of fluorescent polystyrene beads (Fluoresbrite ${ }^{\circledR}$ YG, Polysciences) before and after each series of analysis. Forward light scatter (FSC), side light scatter (SSC), orange fluorescence (570 to $610 \mathrm{~nm})$ and red fluorescence $(>630 \mathrm{~nm})$ were recorded in the list mode by using red fluorescence as a trigger parameter to exclude nonalgal particles and processed using FloMax ${ }^{\circledR}$ (Partec). The instrument settings were standardized for all variables by using $2 \mu \mathrm{m}$ fluorescent beads.

On an orange versus red fluorescence cytogram, Cyanobacteria were distinguished by their bright orange fluorescence (Fig. 2). They were then divided into 2 groups: Synechococcus, or pico-sized Cyanobacteria, with weaker fluorescence and nanocyanobacteria with stronger fluorescence. In the subarctic water, a cyanobacterium-like cluster was frequently observed on an orange versus red fluorescence cytogram, although their orange fluorescence intensity was weak relative to the fluorescence observed for Cyanobacteria. This cluster was considered to be composed of cryptophytes, and not Cyanobacteria, based on the following 3 observations. (1) HPLC pigment analysis of the same water sample revealed the occurrence of alloxanthin, a pigment specific to cryptophytes. (2) The cluster of a cultured strain of the cryptophyte Rhodomonas salina CCMP 1319 appeared on a

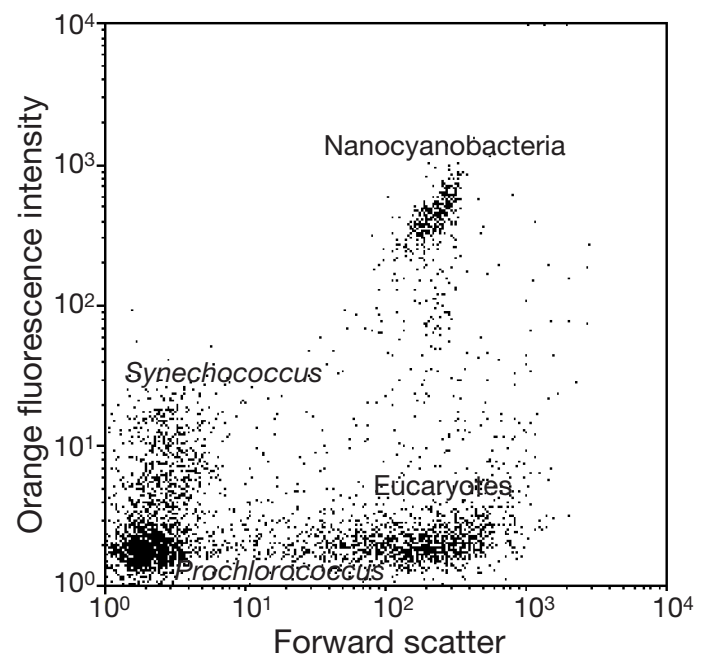

Fig. 2. Cytogram of orange phycoerythrin fluorescence intensity versus forward light scatter (index of cell size) of a sample collected from the surface at $14^{\circ} 34^{\prime} \mathrm{N}, 152^{\circ} 11^{\prime} \mathrm{E}$

similar area on an orange versus red fluorescence cytogram. (3) Under an epifluorescence microscope, orange oval cells that were totally different from coccoid unicellular Cyanobacteria were observed in the subarctic samples when observed under blue light. Although Prochlorococcus appeared at a high cell concentration at all the sampling stations in the subtropical and tropical provinces, they possessed very faint autofluorescence, which was sometimes below the detection limit and resulted in an underestimation of their abundance. Therefore, in the present study, they were excluded from analyses.

It should be noted that 'nanocyanobacteria' in the present study are defined from flow cytometric signatures, not from their genetic characteristics or ecological functions. Actually, flow cytometric counts of nanosized Cyanobacteria and nifH gene copies of Group B cyanobacteria were not always similar (Zehr et al. 2007). However, their flow cytometric signatures were not indistinguishable from those of cultured diazotorphic nano-sized Cyanobacteria (Campbell et al. 2005) and it is highly probable that at least some fraction of them is diazotrophic. In the present study, we operationally use the term 'nanocyanobacteria' to express this phylogenetically diverse group with similar morphology and pigmentation.

During the KH-04-5, KH-05-2 and the Umitaka-maru 0407 cruises, nanomolar levels of nutrients (nitrate + nitrite and soluble reactive phosphorus) were continuously monitored for the surface water collected using the pump installed underneath the ship. Details of the analysis and the results of nutrient measurements at nanomolar levels are described in Hashihama et al. (2009). 


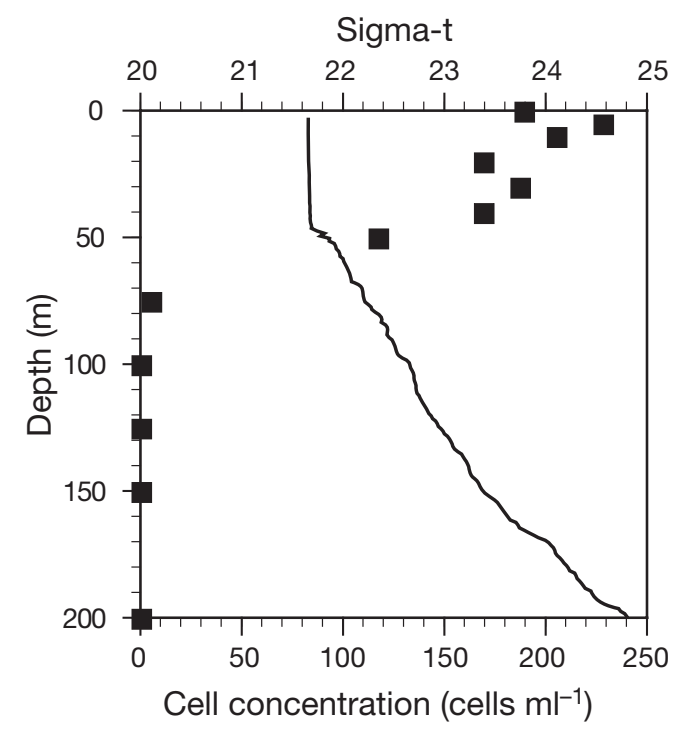

Fig. 3. Vertical distribution of nanocyanobacteria (squares) and sigma-t (solid line) in the central North Pacific $\left(11^{\circ} 30^{\prime} \mathrm{N}\right.$, $155^{\circ} \mathrm{W}$ ). Sigma-t was calculated by substracting 1 from the water density $\left(\mathrm{g} \mathrm{ml}^{-1}\right)$ and multiplying the remainder by 1000

\section{RESULTS}

Nanocyanobacteria were detected in 323 of the 489 stations surveyed. The flow cytometric signatures of the Cyanobacteria were similar at every station; forward light scatter intensity indicated that the spherical equivalent diameter of the cells was approximately 3.5 to $7 \mu \mathrm{m}$. At all the depth-profile stations in the subtropical waters, nanocyanobacteria exhibited similar vertical distributions where their cell concentration was high (e.g. $>100$ cells $\mathrm{ml}^{-1}$ ) and relatively constant within the surface mixed layer and approached zero below the pycnocline (Fig. 3), as observed previously (Neveux et al. 1999, Campbell et al. 2005). This observation validates the use of cell concentration at the surface as a representative value of the cell concentration within the whole mixed layer. Therefore, depth-integrated abundance of nanocyanobacteria was calculated as a product of the cell concentration at the surface and a mixed layer depth derived from monthly mean data from the World Ocean Atlas (1994) (available at: www.nodc.noaa.gov/OC5/WOA94/mix.html). For the stations where the depth profile was obtained, the depth-integrated abundance was calculated by trapezoidal approximation.

The extensive survey of nanocyanobacteria in the Pacific Ocean clearly revealed 2 zones with high nanocyanobacterial abundance in the subtropical regions of both hemispheres (Fig. 4A,B). Areas with cell abundance of $>5 \times 10^{9}$ cells $\mathrm{m}^{-2}$ were confined to the regions between 12 and $27^{\circ} \mathrm{N}$ and 10 and $21^{\circ} \mathrm{S}$. Particularly high abundance (e.g. $>5 \times 10^{10}$ cells m$^{-2}$ ) was observed to the west of $150^{\circ} \mathrm{W}$ within the North Pacific subtropical gyre (NPSG) and the South Pacific subtropical gyre (SPSG).

On the contrary, the other subtropical and tropical provinces, e.g. the Warm Pool (WARM), East Australian Coastal Province (AUSE), eastern regions of the NPSG and SPSG, and the Kuroshio Current Province (KURO), contained fewer nanocyanobacteria (Fig. 4A,B). Within the NPSG, there was a zonal variation in the abundance of nanocyanobacteria. The central (along the $155^{\circ} \mathrm{W}$ transect) and western regions contained high numbers of nanocyanobacteria, while in the eastern region, the abundance was $<3 \times 10^{9}$ cells $\mathrm{m}^{-2}$, although the sampling points were sparse. The occurrence of nano-sized Cyanobacteria had not been reported from a previous survey in the eastern region of the SPSG (Masquelier \& Vaulot 2008), suggesting that nanocyanobacteria are constantly scarce in this region.

When focusing on the western region of the NPSG, nanocyanobacterial abundance varied both spatially and temporarily. This region showed a latitudinal gradient in nanocyanobacterial abundances; they were less abundant in the northern area (Fig. 4A,B). The latitudinal variation was not continuous but rather abrupt, and the front of their abundance appeared at 18,21 and $19^{\circ} \mathrm{N}$ during the $\mathrm{KH}-04-5, \mathrm{KH}-05-2$ and $\mathrm{KH}-$ 08-2 cruises, respectively. Along the $155^{\circ} \mathrm{W}$ transect, the area with high abundance $\left(>5 \times 10^{10}\right.$ cells $\left.\mathrm{m}^{-2}\right)$ of nanocyanobacteria extended to $27^{\circ} \mathrm{N}$, near the northern limit of the NPSG.

The comparison of the KH-04-5 and KH-08-2 cruises, which covered a similar area $\left(10\right.$ to $18^{\circ} \mathrm{N}, 145$ to $155^{\circ} \mathrm{E}$, Fig. 1) in different seasons showed that the average cell abundance between 18 and $10^{\circ} \mathrm{N}$ was significantly lower (2-tailed Student's $t$-test, $\mathrm{p}<0.01$ ) during the $\mathrm{KH}-04-5$ cruise in winter $\left(6.58 \pm 3.12[\mathrm{SD}] \times 10^{9}\right.$ cells $\mathrm{m}^{-2}, \mathrm{n}=10$ ) than during the $\mathrm{KH}-08-2$ cruise in summer $\left(2.80 \pm 2.90 \times 10^{10}\right.$ cells $\left.\mathrm{m}^{-2}, \mathrm{n}=19\right)$. The difference in the surface cell concentration between the 2 cruises was much greater, because the mixing layer depth was approximately 5 times shallower in summer. However, it is unclear whether this difference is attributable to seasonality generally observed in this region. In the KH-08-2 cruise, a water patch with extraordinarily high nanocyanobacterial abundance was observed (dashed circle in Fig. 4B), which greatly contributed to high average abundance in summer.

Similar spatial variation was also evident within the SPSG. Areas with high concentrations were confined to the western region, and the abundance was consistently $<2 \times 10^{9}$ cells $\mathrm{m}^{-2}$ to the east of $150^{\circ} \mathrm{W}$. However, spatial variability was also considerably high within the western region (Fig. 4C). Generally, a high concentration of nanocyanobacteria was observed near islands, although the cell concentration was relatively 

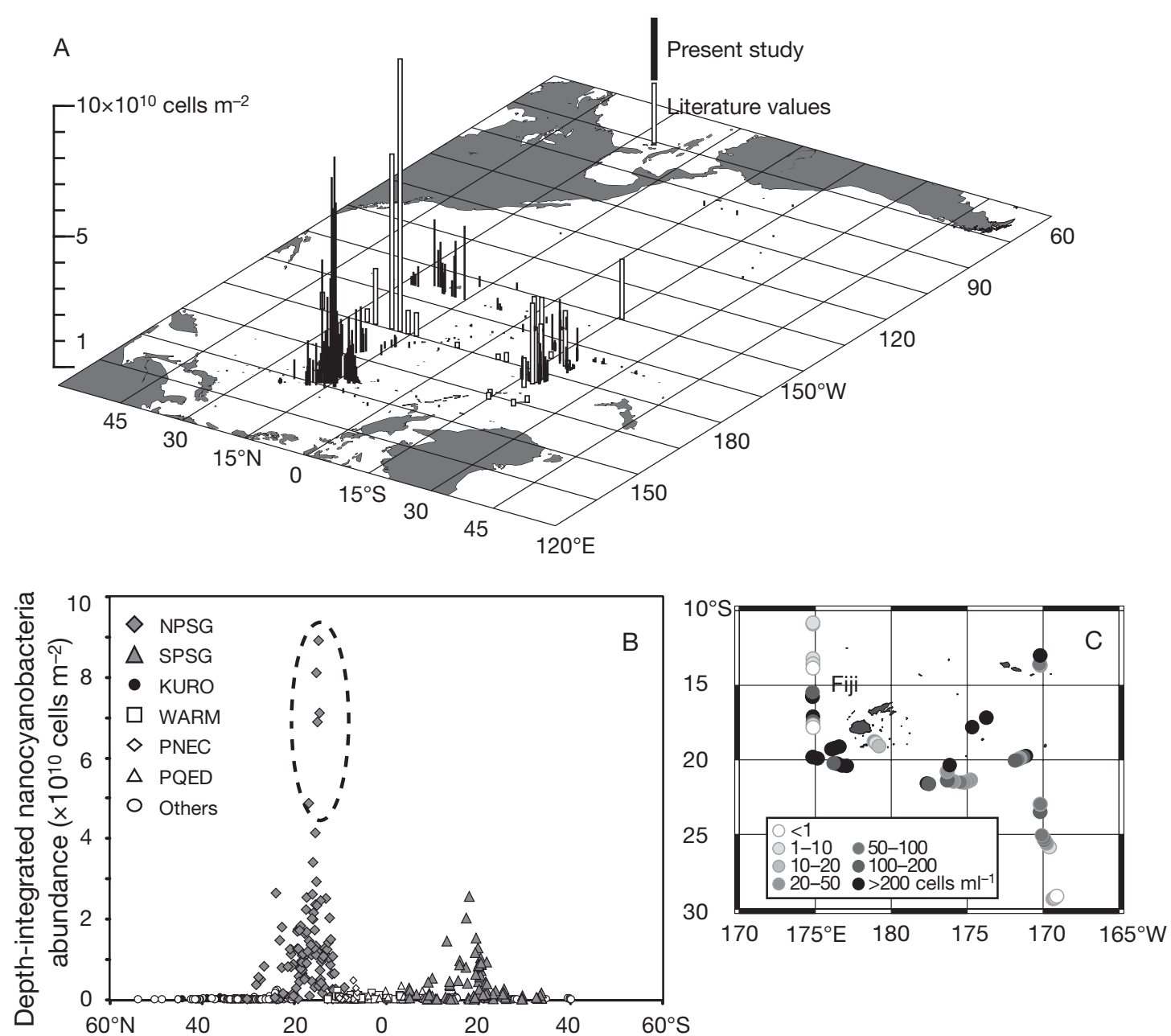

Fig. 4. (A) Depth-integrated abundance of nanocyanobacteria in the Pacific Ocean, as determined by flow cytometry (filled bars). Previous estimates of depth-integrated abundance (Ishizaka et al. 1994, Neveux et al. 1999, Campbell et al. 2005) are shown by open bars. (B) Meridional distribution of nanocyanobacteria at the surface in ecological provinces (see Fig. 1 for abbreviations) in the Pacific Ocean. Five data points enclosed with dashed line are from a water patch with extraordinarily high abundance of nanocyanobacteria observed around $14.5^{\circ} \mathrm{N}, 152^{\circ} \mathrm{E}$, during the KH-08-2 cruise. (C) Surface cell concentrations of the nanocyanobacteria around the islands of Fiji

low $\left(\sim 25\right.$ cells $\mathrm{ml}^{-1}$ at the surface) off the west coast of Viti Levu Island, Fiji, while the concentration was extremely high (sometimes $>500$ cells $\mathrm{ml}^{-1}$ at the surface) off the eastern coast. Interestingly, the low abundance of nanocyanobacteria was accompanied by high abundance of filamentous diazotrophic Cyanobacteria Trichodesmium spp., and vice versa (Hashihama et al. 2010).

For the estimation of the relative contribution to planktonic biomass, their depth-integrated (0 to $200 \mathrm{~m}$ ) biomass was calculated for depth-profile stations during the KH-05-2 and KH-08-2 cruises (Fig. 5) by trapezoidal approximation using reported cellular carbon biomass from cultured Cyanobacteria. As a carbon conversion coefficient, 2200 and $170 \mathrm{fg} \mathrm{C}^{\mathrm{C}} \mathrm{cell}^{-1}$ were adopted for nanocyanobacteria and Synechococcus, respectively, from the average values for cultured Crocosphaera watsonii (Tuit et al. 2004) and Synechococcus (Bertilsson et al. 2003), respectively. Data at the surface monitoring stations were excluded, because vertical profiles of Synechococcus had a distinct subsurface maximum, which makes it difficult to estimate depth-integrated biomass only from the surface cell abundance. The variation in cell size by depth was neglected in the present calculation for simplification. The latitudinal distribution of nanocyanobacteria in the subtropical and tropical waters was largely a mirror image of that of pico-sized Cyanobacteria Synechococcus (Fig. 5). The contribution of nanocyanobacteria was comparable with or larger than Synechococcus between 10 and $20^{\circ} \mathrm{N}$, while in the other regions, Synechococcus was overwhelmingly dominant. 


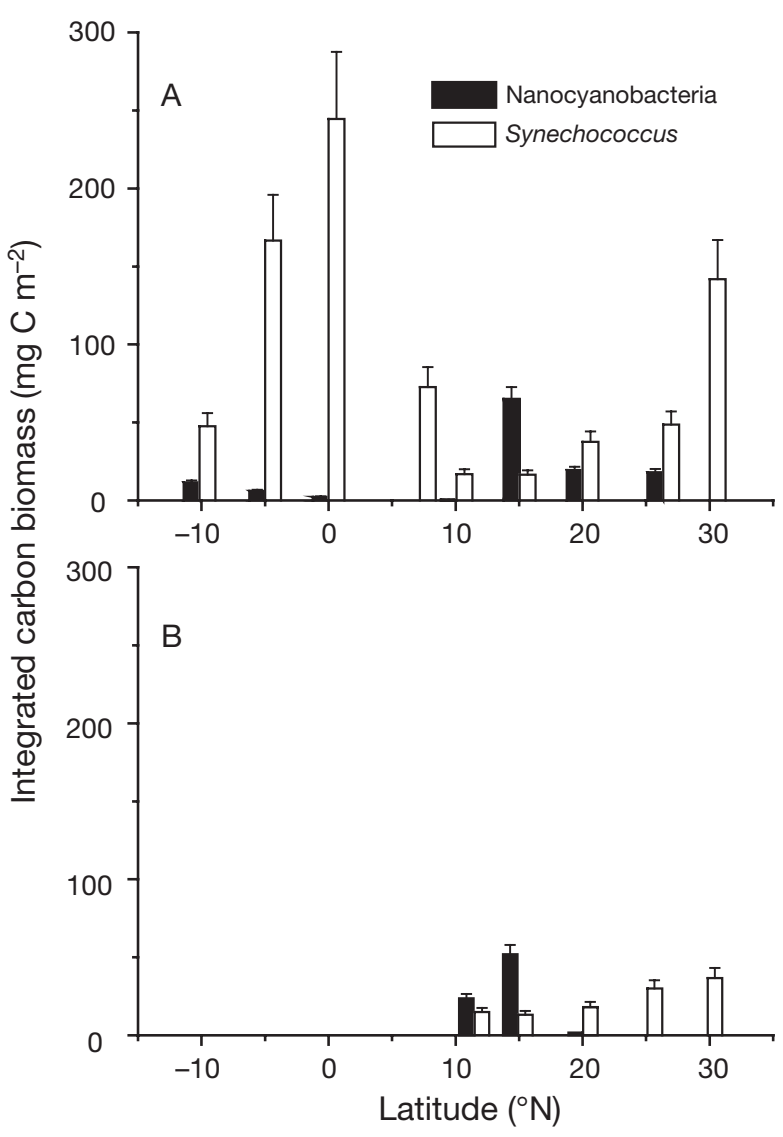

Fig. 5. Latitudinal distributions of depth-integrated carbon biomass of nanocyanobacteria (filled bar) and Synechococcus (open bar) on the southeast-northwest transects during the (A) KH-05-2 and (B) KH-08-2 summer cruises (see Fig. 1 for details). All the data were derived from the depth-profile stations. Biomass was estimated from vertical profiles of their cell abundance derived in the present study and cellular carbon biomass in the literature (see 'Results'). Error bars indicate SE of the estimation of cellular carbon content

\section{DISCUSSION}

\section{What controls nanocyanobacterial abundance?}

In many previous studies, factor analysis or multiple regression analysis has been used to explain horizontal or temporal variations in microbial communities from environmental factors (Booth et al. 1993, Martin et al. 2008, Zwirglmaier et al. 2008). However, in this study, such a statistical method that uses various environmental conditions as explanatory variables of nanocyanobacerial abundance was not applied for 2 reasons. (1) The relationship between nanocyanobacterial abundance and a specific environmental variable was not always linear. The area replete with nanocyanobacteria occurred within a very narrow range of temperature or nutrient concentrations, as detailed in the
'Results' and the following discussion. (2) Distinctly different abundances of nanocyanobacteria were observed in the different provinces with similar environmental conditions, as documented in detail in the following paragraphs. Thus, in this discussion, to elucidate what controls nanocyanobacterial abundance in each province, we analyzed the data set for an individual environmental chemical and physical variable or ocean province, rather than applying statistical analysis for the whole data set.

Generally, the areas with high abundance of nanocyanobacteria (NPSG and SPSG, Fig. 4) are characterized by nitrate depletion at the nanomolar level (Hashihama et al. 2009), high temperature $\left(>25^{\circ} \mathrm{C}\right.$ ) and relatively high irradiance. It is remarkable that nanocyanobacteria can survive in this environment with extremely low nitrate concentrations, despite their relatively low cell surface:volume ratio compared with pico-sized $(\sim 1 \mu \mathrm{m})$ Cyanobacteria Synechococcus, which are abundant in the subtropical open ocean ( $\mathrm{Li}$ \& Wood 1988, Shimada et al. 1993). These areas with high nanocyanobacterial abundance largely correspond with those with high nitrogen fixation activity as inferred from the nutrient concentration data (Deutsch et al. 2001) or the isotopic composition of nitrogen in suspended materials (Chen et al. 2006). These observations strongly suggest that some of nanocyanobacteria can use nitrogen fixation to obtain reduced nitrogen, as demonstrated previously (Zehr et al. 2001).

One possible factor that controls their biomass in the subtropical and tropical areas other than the western and central NPSG and SPSG is the low supply of iron, which is essential for all phytoplankton. Iron is particularly indispensable for diazotrophs, since it is present in the reaction center of nitrogenase, an essential enzyme responsible for nitrogen fixation. The nitrogen-fixing nanocyanobacterium Crocosphaera wastonii requires a greater amount of iron compared with the other phytoplankton; especially during nitrogen fixation, their iron demand increases by more than 3 times (Tuit et al. 2004), implying that they are vulnerable to iron limitation. In the eastern region of the SPSG and the warm pool in the western Pacific (WARM), nanocyanobacterial abundance was low compared with the other subtropical regions (Fig. 4), although a detectable level (>50 nM) of phosphate has been observed (Moutin et al. 2008, Hashihama et al. 2009). The low abundance is probably explained by iron limitation, because these 2 regions are known to receive low annual dust deposition (Jickells et al. 2005), which implies an ecological disadvantage of diazotrophy there.

The depth of the surface mixed layer may also affect the abundance of nanocyanobacteria. For example, the deepening of the mixed layer would reduce the aver- 


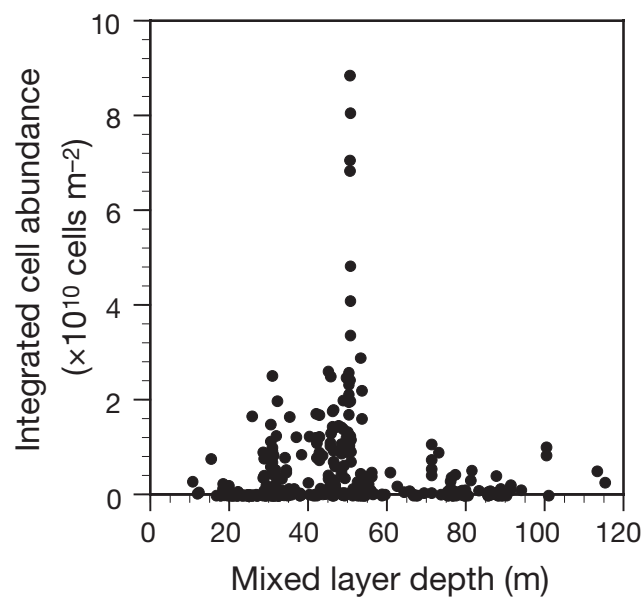

Fig. 6. Relationship between the depth-integrated cell abundance of nanocyanobacteria and the mixed layer depth. Mixed layer depth was derived from CTD observations and the World Ocean Atlas for a depth-profile station and surfacemonitoring station, respectively (see 'Materials and methods'). The data points are confined to the data collected between $30^{\circ} \mathrm{N}$ and $30^{\circ} \mathrm{S}$ to focus on subtropical and tropical waters

age irradiance. In the present study, the correlation between depth-integrated nanocyanobacterial abundance and mixed layer depth determined from CTD profiles or derived from the World Ocean Atlas was not significant ( $p>0.1$; Fig. 6), although their abundance substantially decreases in regions with a mixed layer depth $>60 \mathrm{~m}$. This suggests that the deepening of the mixed layer can have a disadvantageous effect on nanocyanobacteria, probably through light limitation. The lower nanocyanobacterial abundance in the NPSG observed in winter than in summer can be explained by this mechanism. On the contrary, the abundance of Synechococcus and pico-sized eukaryotic phytoplankton is generally higher in winter (Campbell et al. 1997), probably due to higher availability of nutrients supplied from the deep layer. This suggests that for nanocyanobacteria, which probably include nitrogen fixers, the cost of light limitation is larger than the benefit of enhanced nutrient supply in winter. Simultaneously, the deepening of the mixed layer would provide nitrate from the deep layer, which would decrease the ecological advantage of nitrogenfixing nanocyanobacteria (Agawin et al. 2007).

During the KH-04-5 and KH-05-2 cruises, the position of the front largely coincided with the border of the area depleted with surface soluble reactive phosphorus and the area with detectable soluble reactive phosphorus (Fig. 7, Hashihama et al. 2009). These results are similar with those of molecular biological surveys previously conducted in the central Pacific Ocean (Church et al. 2008), although those investiga- tors attributed the spatial variations in nitrogenase abundance to ocean frontal systems. The present results show that the front of nanocyanobacterial abundance in the NPSG did not coincide with the ocean front as inferred from salinity or temperature, suggesting instead that the northern limit of the area rich in nanocyanobacteria in the NPSG is determined by availability of phosphorus. In the southern hemisphere as well, soluble reactive phosphorus was detectable in the area abundant in nanocyanobacteria, namely in the western part of the SPSG (Hashihama et al. 2009). These observations strongly suggest that one of the requisites for prosperity of nanocyanobacteria is that surface reactive phosphorus is not depleted. The inability of nano-sized Cyanobacteria to grow on some types of organic phosphorus compounds (Dyhrman \& Haley 2006) may affect their distribution.

However, the low concentration of nanocyanobacteria in the eastern coastal area of Australia (AUSE) cannot be explained by the factors documented above. In this province, nitrate was depleted $(<10 \mathrm{nM})$ at the surface, while soluble reactive phosphorus was higher than in the NPSG or SPSG (>100 nM, Hashihama et al. 2009). Additionally, dust deposition from Australian deserts is high (Jickells et al. 2005). On the contrary, there is a report that dissolved iron concentrations at the surface of this region were relatively low $(0.1$ to $0.3 \mathrm{nM}$ ), probably limiting phytoplankton productivity (Obata et al. 2008). Whether iron can actually control nanocyanobacterial abundance in this province should be examined in future studies.

In addition to the cross-basin scale variations, mesoscale fluctuations in nanocyanobacterial abundance were observed. One example is a water patch with high abundance of nanocyanobacteria, observed around $14.5^{\circ} \mathrm{N}, 152^{\circ} \mathrm{E}$ during the KH-08-2 cruise (Fig. 4B). Also, eddies in the subtropical water have been reported to affect abundance of diazotrophs including Trichodesmium (Davis \& McGillicuddy 2006) and Crocosphaera watsonii (Fong et al. 2008). However, the patch observed in the present study was not accompanied by any apparent variation in surface salinity, temperature or sea level anomaly obtained from the website of the Colorado Center for Astrodynamics Research (available at: argo.colorado.edu/ realtime/gsfc_global-real-time_ssh/). From the present study, it was not revealed what processes induced the mesoscale accumulation of nanocyanobacteria.

\section{Relationships with other Cyanobacteria}

Nanocyanobacteria in the subtropical and tropical oceans are probably in a competitive relationship with other nondiazotrophic and diazotrophic Cyanobacte- 

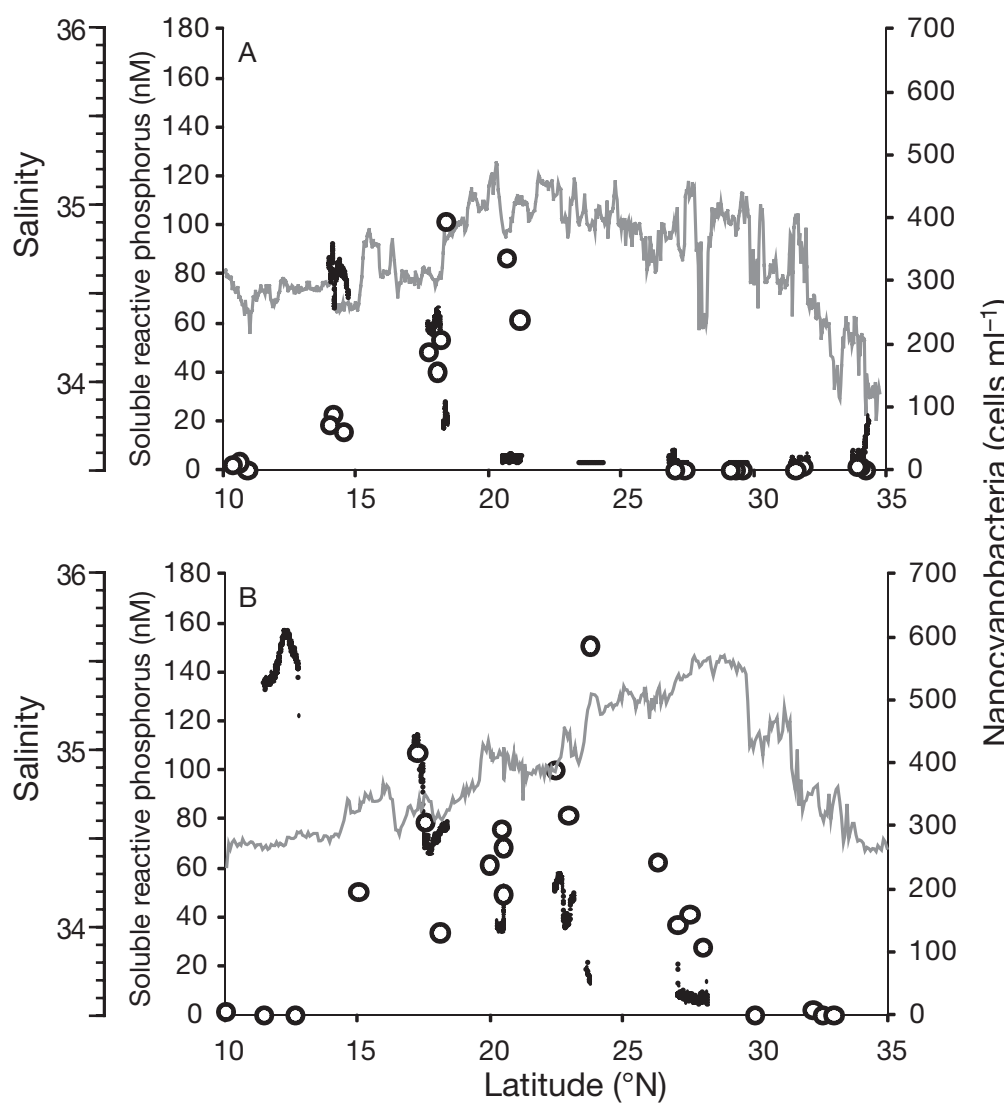

Fig. 7. Latitudinal variation of the surface cell concentration of nanocyanobacteria (open circle), together with surface salinity (grey line) and soluble reactive phosphorous (SRP) concentration (intermittent black traces) on the (A) northwest-southeast $\left(140\right.$ to $\left.180^{\circ} \mathrm{E}\right)$ and (B) south-north $\left(160^{\circ} \mathrm{W}\right)$ transects during the KH-05-2 cruise. SRP concentration data were derived from Hashihama et al. (2009)

ria. A plot of nanocyanobacterial abundance against that of pico-sized Cyanobacteria Synechococcus (Fig. 8) shows that the maximum abundance of nanocyanobacteria appears to be inversely correlated with Synechococcus. Generally, Synechococcus was sparse $\left(<1000\right.$ cells $\mathrm{ml}^{-1}$ at the surface) in subtropical gyres (Fig. 5), where nanocyanobacteria were abundant, while their abundance increased toward the WARM or KURO, where nanocyanobacterial abundance was much smaller and the surface nitrate level was higher (i.e. nanomolar level) (Hashihama et al. 2009). This observation on Synechococcus abundance is consistent with previous reports (e.g. Jiao et al. 2005) that they were numerically abundant in the water with high availability of nutrients. These results suggest that nanocyanobacteria probably prosper where Synechococcus are limited by low availability of nutrients, especially nitrate, as observed in competition experiments using laboratory cultures (Agawin et al. 2007).
The patchy distribution of nanocyanobacteria around the islands of Fiji (Fig. 4C) might be explained by the competition with larger filamentous diazotrophic Cyanobacteria Trichodesmium spp. In this region, Trichodesmium spp. appeared in high abundance where nanocyanobacteria were sparse (Hashihama et al. 2010). The trade-off relationship between nanocyanobacteria and Trichodesmium in this region was also observed by Campbell et al. (2005), suggesting that the 2 types of Cyanobacteria compete for the same limiting resource (iron or phosphate). The cell size of nanocyanobacteria is much smaller than Trichodesmium, which will probably be an advantage for nutrient uptake by nanocyanobacteria. How Trichodesmium can outcompete nanocyanobacteria is a topic to be elucidated in a future study.

The spatial segregation of nanocyanobacteria and other Cyanobacteria (diazotrophic and nondiazotrophic) is implicative in biogeochemical models in the subtropical oceans. The horizontal distribution of nanocyanobacteria revealed in the present study, which is probably affected by nitrogen, phosphorus and iron availability, seems largely consistent with the export model hypothesized by Karl (2002). Nanocyanobacteria in the present study are similar to the $\mathrm{N}_{2}$-fixing bacteria (pico/nano) in his model in that they prosper when nitrate is depleted and phosphorus is not. On the other hand, the fact that the tradeoff relationship between nanocyanobacteria

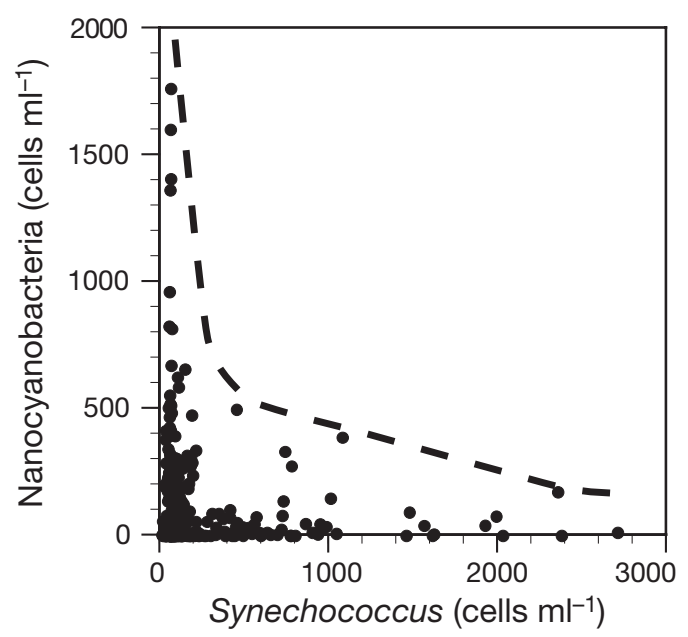

Fig. 8. The surface cell concentration of nanocyanobacteria versus that of pico-sized Cyanobacteria Synechococcus. The data points are confined to the data collected between $30^{\circ} \mathrm{N}$ and $30^{\circ} \mathrm{S}$ to focus on subtropical and tropical waters. Dashed line emphasizes the pattern of the data points 
and Trichodesmium is not explained simply by iron availability suggests that competitive relationships between them are not simple as proposed in the model. The present study suggests that shifts of prosperous microbes between diazotrophic and nondiazotrophic Cyanobacteria or between large and small diazotrophs could occur not only temporally, but also spatially, in response to changes in nutrient availability.

\section{CONCLUSION}

From extensive observations, the high abundance $\left(>5 \times 10^{10}\right.$ cells $\left.\mathrm{m}^{-2}\right)$ of nano-sized Cyanobacteria in the Pacific Ocean was confined to the areas between 12 and $27^{\circ} \mathrm{N}$ and 10 and $21^{\circ} \mathrm{S}$ of the western and central subtropical gyres. These areas are characterized by depleted nitrate, high irradiance and temperature and detectable reactive phosphorus. Within these areas, their abundance was possibly controlled by irradiance and they might compete with nondiazotrophic picosized Cyanobacteria Synechococcus and filamentous diazotrophic Cyanobacteria Trichodesmium. In the other subtropical and tropical waters, their abundance was comparatively low, probably limited by phosphorus or iron availability.

In future studies, the examination of limiting factors of nanocyanobacterial growth in the natural environment is essential to reveal what controls their abundance and their role in the nitrogen biogeochemical cycle. At least some portion of the nanocyanobacteria are diazotrophic, but the nitrogen fixed by them is expected to be efficiently regenerated through microbial food webs, contrary to that by larger diazotrophs including Trichodesmium, which can escape grazing more efficiently due to their size. Therefore, the observation that large and small diazotrophic and nondiazotrophic Cyanobacteria were geographically segregated within the subtropical and tropical open waters suggests that the mechanism of biogeochemical cycling of nitrogen is not uniform within these areas, but is rather patchy.

Acknowledgements. We greatly appreciate P. J. Harrison for suggestive comments on this manuscript. We thank all the crews and officers of RV 'Hakuho-maru', RV 'Mirai' and RTV 'Umitaka-maru' for their assistance in sample collection. This research was supported by Japanese Society for the Promotion of Science (JSPS) grant nos. 14658151, 17651003, 12NP0201 (DOBIS), 18067006, 18067007 and 19030005.

\section{LITERATURE CITED}

Agawin NSR, Rabouille S, Veldhuis MJW, Servatius L, Hol S, van Overzee HMJ, Huisman J (2007) Competition and facilitation between unicellular nitrogen-fixing cyanobacteria and non-nitrogen fixing phytoplankton species. Limnol Oceanogr 52:2233-2248
Bertilsson S, Berglund O, Karl DM, Chisholm SW (2003) Elemental composition of marine Prochlorococcus and Synechococcus: implications for the ecological stoichiometry of the sea. Limnol Oceanogr 48:1721-1731

Booth BC, Lewin J, Postel JR (1993) Temporal variation in the structure of autotrophic and heterotrophic communities in the subarctic Pacific. Prog Oceanogr 32:57-99

Campbell L, Vaulot D (1993) Photosynthetic picoplankton community structure in the subtropical North Pacific Ocean near Hawaii (station ALOHA). Deep-Sea Res I 40: 2043-2060

> Campbell L, Liu H, Nolla HA, Vaulot D (1997) Annual variability of phytoplankton and bacteria in the subtropical North Pacific Ocean at Station ALOHA during the 1991-1994 ENSO event. Deep-Sea Res I 44:167-192

Campbell L, Carpenter EJ, Montoya JP, Kustka AB, Capone DG (2005) Picoplankton community structure within and outside Trichodesmium bloom in the southwestern Pacific Ocean. Vie Milieu 5:185-195

$>$ Capone DG, Ferrier MD, Carpenter EJ (1994) Amino acid cycling in colonies of the planktonic marine cyanobacterium Trichodesmium thiebautii. Appl Environ Microbiol 60:3989-3995

Capone DG, Zehr JP, Paerl HW, Bergman B, Carpenter EJ (1997) Trichodesmium, a globally significant marine cyanobacterium. Science 276:1221-1229

Chen M, Guo L, Ma Q, Qiu Y, Zhang R, Lv E, Huang Y (2006) Zonal patterns of $\delta^{13} \mathrm{C}, \delta^{15} \mathrm{~N}$ and ${ }^{210} \mathrm{Po}$ in the tropical and subtropical North Pacific. Geophys Res Lett 33:L04609 doi:10.1029/2005GL025186

Church MJ, Jenkins BD, Karl DM, Zehr JP (2005) Vertical distributions of nitrogen-fixing phylotypes at Stn ALOHA in the oligotrophic North Pacific Ocean. Aquat Microb Ecol 38:3-14

Church MJ, Björkman KM, Karl DM, Saito MA, Zehr JP (2008) Regional distribution of nitrogen-fixing bacteria in the Pacific Ocean. Limnol Oceanogr 53:63-77

> Davis CS, McGillicuddy DJ (2006) Transatlantic abundance of the $\mathrm{N}_{2}$-fixing colonial cyanobacterium Trichodesmium. Science 312:1517-1520

> Deutsch C, Gruber N, Key RM, Sarmiento JL, Ganachaud A (2001) Denitrification and $N_{2}$ fixation in the Pacific Ocean. Glob Biogeochem Cycles 15:483-506

Dyhrman ST, Haley ST (2006) Phosphorous scavenging in the unicellular marine diazotroph Crocosphaera watsonii. Appl Environ Microbiol 72:1452-1458

Falcón LI, Carpenter EJ, Cipriano F, Bergman B, Capone DG (2004a) $\mathrm{N}_{2}$ fixation by unicellular bacterioplankton from the Atlantic and Pacific oceans: phylogeny and in situ rates. Appl Environ Microbiol 70:765-770

Falcón LI, Lindvall S, Bauer K, Bergman B, Carpenter EJ (2004b) Ultrastructure of unicellular $\mathrm{N}_{2}$ fixing cyanobacteria from the tropical north Atlantic and subtropical north Pacific oceans. J Phycol 40:1074-1078

> Fong AA, Karl DM, Lukas R, Letelier RM, Zehr JP, Church MJ (2008) Nitrogen fixation in an anticyclonic eddy in the oligotrophic North Pacific Ocean. ISME J 2:663-676

Gruber N, Sarmiento JL (1997) Global patterns of marine nitrogen fixation and denitrification. Glob Biogeochem Cycles 11:235-266

> Hashihama F, Furuya K, Kitajima S, Takeda S, Takemura T, Kanda J (2009) Macro-scale exhaustion of surface phosphorus by dinitrogen fixation in the western North Pacific. Geophys Res Lett 36:L03610. doi:10.1029/2008GL036866

Hashihama F, Sato M, Takeda S, Kanda J, Furuya K (2010) Mesoscale decrease of surface phosphate and associated phytoplankton dynamics in the vicinity of the subtropical 
South Pacific islands. Deep-Sea Res I 57:338-350

Ishizaka J, Kiyosawa H, Ishida K, Ishikawa K, Takahashi M (1994) Meridional distribution and carbon biomass of autotrophic picoplankton in the Central North Pacific Ocean during late northern summer 1990. Deep-Sea Res I 41:1745-1766

Jiao N, Yang Y, Hong N, Ma Y, Harada S, Koshikawa H, Watanabe M (2005) Dynamics of autotrophic picoplankton and heterotrophic bacteria in the East China Sea. Cont Shelf Res 25:1265-1279

Jickells TD, An ZS, Andersen KK, Baker AR and others (2005) Global iron connections between desert dust, ocean biochemistry, and climate. Science 308:67-71

Karl DM (2002) Nutrient dynamics in the deep blue sea. Trends Microbiol 10:410-418

Kitajima S, Furuya K, Hashihama F, Takeda S, Kanda J (2009) Latitudinal distribution of diazotrophs and their nitrogen fixation in the tropical and subtropical western North Pacific. Limnol Oceanogr 54:537-547

Langlois RJ, LaRoche J, Raab PA (2005) Diazotrophic diversity and distribution in the tropical and subtropical Atlantic Ocean. Appl Environ Microbiol 71:7910-7919

Li WKW, Wood AM (1988) Vertical distribution of North Atlantic ultraphytoplankton: analysis by flow cytometry and epifluorescence microscopy. Deep-Sea Res 35: 1615-1638

Longhurst A (2007) Ecological geography of the sea, 2nd edn. Academic Press, London

Martin AP, Zubkov MV, Fasham MJ, Burkill PH, Holland RJ (2008) Microbial spatial variability: an example from the Celtic Sea. Prog Oceanogr 76:443-465

Masquelier S, Vaulot D (2008) Distribution of micro-organisms along a transect in the South-East Pacific Ocean (BIOSOPE cruise) using epifluorescent microscopy. Biogeosciences 5:311-321

Mazard SL, Fuller NJ, Orcutt KM, Bridle O, Scanlan DJ (2004) PCR analysis of the distribution of unicellular cyanobacterial diazotrophs in the Arabian Sea. Appl Environ Microbiol 70:7355-7364

Montoya JP, Holl CM, Zehr JP, Hansen A, Villareal TA,

Editorial responsibility: Douglas Capone,

Los Angeles, California, USA
Capone DG (2004) High rates of $\mathrm{N}_{2}$ fixation by unicellular diazotrophs in the oligotrophic Pacific Ocean. Nature 430: 1027-1031

Moutin T, Karl DM, Duhamel S, Rimmelin P, Raimbault P, Van Mooy BAS, Claustre H (2008) Phosphate availability and the ultimate control of new nitrogen input by nitrogen fixation in the tropical Pacific Ocean. Biogeosciences 5: 95-109

Needoba JA, Foster RA, Sakamoto C, Zehr JP, Johnson KS (2007) Nitrogen fixation by unicellular diazotrophic cyanobacteria in the temperate oligotrophic North Pacific Ocean. Limnol Oceanogr 52:1317-1327

> Neveux J, Lantoine F, Vaulot D, Marie D, Blanchot J (1999) Phycoerythrins in the southern tropical and equatorial Pacific Ocean: evidence for new cyanobacterial types. J Geophys Res 104(C2):3311-3321 doi: 10.1029/98JC02000

Obata H, Shitashima K, Isshiki K, Nakayama E (2008) Iron, manganese and aluminum in upper waters of the western South Pacific Ocean and its adjacent seas. J Oceanogr 64: 233-245

Shimada A, Hasegawa T, Umeda I, Kadoya N, Maruyama T (1993) Spatial mesoscale patterns of West Pacific picophytoplankton as analyzed by flow cytometry: their contribution to subsurface chlorophyll maxima. Mar Biol 115: 209-215

Tuit C, Waterbury J, Ravizza G (2004) Diel variation of molybdenum and iron in marine diazotrophic cyanobacteria. Limnol Oceanogr 49:978-990

Zehr JP, Waterbury JB, Turner PJ, Montoya JP and others (2001) Unicellular cyanobacteria fix $\mathrm{N}_{2}$ in the subtropical North Pacific Ocean. Nature 412:635-638

Zehr PJ, Montoya JP, Jenkins BD, Hewson I and others (2007) Experiments linking nitrogenase gene expression to nitrogen fixation in the North Pacific subtropical gyre. Limnol Oceanogr 52:169-183

Zwirglmaier K, Jardillier L, Ostrowski M, Mazard S and others (2008) Global phylogeography of marine Synechococcus and Prochlorococcus reveals a distinct partitioning of lineages among oceanic biomes. Environ Microbiol 10: $147-161$

Submitted: March 23, 2009; Accepted: December 19, 2009 Proofs received from author(s): April 8, 2010 